\title{
Soil nitrogen dynamics and leaching under conservation tillage in the Atlantic Coastal Plain, Georgia, United States
}

\section{O. Pisani, T.C. Strickland, R.K. Hubbard, D.D. Bosch, A.W. Coffin, D.M. Endale, and T.L. Potter}

\begin{abstract}
Conservation tillage (CsT) involves management that reduces soil erosion by maintaining crop residue cover on farm fields. Typically, both infiltration and soil organic matter increase over time with CsT practices. We compared the impact of a commonly used CsT practice, strip tillage (ST), to conventional tillage (CT) management on soil nitrogen (N) dynamics and leaching and examined associations to soil $\mathrm{N}$ availability and microbial biomass. A winter cover crop was used in both tillage treatments. The study was conducted over a five-year period during rotational cotton (Gossypium hirsutum L.) and peanut (Arachis hypogaea L.) production in the Atlantic Coastal Plain region in Georgia, United States. Fertilizer and poultry litter were applied ahead of the cotton crops. Sets of PVC cylinders were filled with soil from each of six plots, three in ST and three in CT, and maintained in situ in their respective plots for 16 intervals of about 90 days. After retrieval, the soil in each cylinder was analyzed for inorganic $\mathrm{N}$ (ammonium and nitrates $\left[\mathrm{NH}_{4}^{+}\right.$and $\left.\mathrm{NO}_{3}^{-}\right]$), total $\mathrm{N}$, total carbon (C), and microbial biomass. Leached $\mathrm{NO}_{3}^{-}-\mathrm{N}$ was captured on anion exchange resin-filled bags attached to the bottom of each cylinder. After the five-year study period, the ST and CT soil C content increased by $22 \%$ and $23 \%$, respectively. Total soil $\mathrm{N}$ content increased $27 \%$ with ST compared to $22 \%$ with $\mathrm{CT}$. Temporal patterns in $\mathrm{NO}_{3}^{-}-\mathrm{N}$ leaching were not different between CT and ST treatments, and a high amount of $\mathrm{NO}_{3}^{-}-\mathrm{N}$ leaching was observed after the application of poultry litter. The cumulative amount of $\mathrm{NO}_{3}^{-}-\mathrm{N}$ leached from soils throughout the five-year study was 141 and $122 \mathrm{~kg} \mathrm{~N} \mathrm{ha}^{-1}\left(126\right.$ and $109 \mathrm{lb} \mathrm{N} \mathrm{ac}{ }^{-1}$ ) with CT and ST practices, respectively. Results suggest that leaching from the top $15 \mathrm{~cm}(6$ in) of soil may be an important pathway of $\mathrm{N}$ loss from both CT and ST cropping systems in the region. Regardless of tillage, soil microbial biomass $\mathrm{N}$ was equal to or higher than the total inorganic N, but still represented a small percentage (up to $9 \%$ ) of the total soil $\mathrm{N}$. Overall, microbial biomass $\mathrm{N}$ was higher in ST compared to CT. Minimizing $\mathrm{NO}_{3}^{-}-\mathrm{N}$ in the soil from reaching ground and surface waters while increasing crop productivity represents a major challenge. The use of ST in conjunction with winter cover crops may improve plant $\mathrm{N}$ availability by more than $27 \mathrm{~kg} \mathrm{ha}^{-1} \mathrm{y}^{-1}\left(24 \mathrm{lb} \mathrm{ac}^{-1} \mathrm{yr}^{-1}\right)$ in the sandy landscapes of the southeastern Coastal Plain region through microbial cycling of organic $\mathrm{N}$ while reducing subsurface $\mathrm{NO}_{3}^{-}-\mathrm{N}$ losses.
\end{abstract}

Key words: Conservation Effects Assessment Project (CEAP)—crop residue-Greenhouse gas Reduction through Agricultural Enhancement network (GRACEnet)-Long-Term Agroecosystem Research (LTAR) Network-microbial biomass—strip tillage

\begin{abstract}
Conservation tillage (CsT) involves management practices that focus on reducing soil erosion and degradation (Holland 2004; Lal et al. 2007). These practices are defined by minimum or no soil disturbance, permanent residue cover on $30 \%$ or more of the soil surface after planting, direct sowing, and crop rotation (Schnepf and Cox
\end{abstract}

increase soil carbon (C) and nitrogen (N) accretion (Strickland et al. 2015), and reduce sediment runoff (Endale et al. 2014) and agrichemical loss (Potter et al. 2014, 2015) in the region. Soils under CsT management have less soil disturbance compared to conventional tillage $(\mathrm{CT})$, which can lead to the accumulation of potentially mineralizable substrates and greater soil microbial biomass (Causarano et al. 2008). Implementing CsT practices in the southeastern Coastal Plain has many potential benefits. However, more information is needed to determine tillage effects on the interactions between different soil organic matter (SOM) pools, soil $\mathrm{N}$ speciation, and $\mathrm{N}$ leaching loss in this region.

Nitrogen is added to soils in the form of commercial fertilizers, animal manure, waste water effluent, and crop residues (Kalkhoff et al. 2016). The soil $\mathrm{N}$ that is not taken up by plants is incorporated into SOM, lost to the atmosphere, or leached into ground, surface, or subsurface water (Bosch et al. 2015; Di and Cameron 2002). The concentration of ammonium $\left(\mathrm{NH}_{4}^{+}\right)$in most soils is usually low because it is readily converted to nitrate $\left(\mathrm{NO}_{3}{ }^{-}\right)$. Because $\mathrm{NO}_{3}^{-}$is a water-soluble and mobile form of $\mathrm{N}$, it is not retained by the soils and is susceptible to leaching. Nitrate leaching occurs when fertilization rates are in excess of plant uptake and occurs in conjunction with or followed by a high drainage volume (Di and Cameron 2002). This mechanism of $\mathrm{N}$ loss from soils can be a source of contamination to surface and groundwater and is a health concern for both humans and animals (Di and Cameron 2002; Iversen et al. 1998; Thorburn et al. 2003).

Movement of $\mathrm{NO}_{3}^{-}-\mathrm{N}$ to groundwater is of concern in the southeastern Coastal Plain because of the climate, soil morphology, and geohydrologic regimes of the region (Hubbard et al. 2004). The southeastern Coastal Plain is characterized by warm temperatures, high rainfall, and sandy textured

Oliva Pisani is a research chemist and Timothy C. Strickland is a supervisory soil scientist at the Southeast Watershed Research Laboratory, USDA Agricultural Research Service (ARS) in Tifton, Georgia. Robert K. Hubbard is a retired soil scientist for the USDA ARS in Tifton, Georgia. David D. Bosch is a research hydraulic engineer, Alisa W. Coffin is a research ecologist, Dinku $M$. Endale is a research agricultural engineer, and Thomas L. Potter is a research chemist at the Southeast Watershed Research Laboratory, USDA ARS in Tifton, Georgia. 
soils. The weathered soils of the region require relatively high $\mathrm{N}$ inputs for adequate crop production. Studies in the southeastern Coastal Plain have indicated that $\mathrm{NO}_{3}^{-}-\mathrm{N}$ in shallow groundwater and shallow subsurface flow often exceeds the $10 \mathrm{mg} \mathrm{L}^{-1}(0.002$ $\mathrm{OZ} \mathrm{gal}^{-1}$ ) standard established by the US Environmental Protection Agency (USEPA) (Hubbard and Sheridan 1983; Hubbard et al. 1986) and as much as $20 \%$ of fertilizer $\mathrm{N}$ input can be lost via shallow subsurface flow (Hubbard and Sheridan 1983). A more recent study (Bosch et al. 2015) evaluated tillage impacts on surface and subsurface $\mathrm{N}$ $\left(\mathrm{NH}_{4}^{+}\right.$and $\left.\mathrm{NO}_{3}^{-}\right)$loads in this region and showed that over a five-year period the $\mathrm{N}$ subsurface flow loading was equivalent to $8.3 \%$ and $18.4 \%$ of the total $\mathrm{N}$ applied to CT and ST fields, respectively. Surface runoff loads were found to represent a much smaller pathway for $\mathrm{N}$ loss, equivalent to $1.5 \%$ and $1 \%$ of the total $\mathrm{N}$ applied to CT and ST fields, respectively.

Soil $\mathrm{N}$ speciation and $\mathrm{NO}_{3}^{-}-\mathrm{N}$ leaching are linked to soil microbial biomass (Herai et al. 2006), which can be measured by the chloroform fumigation-extraction technique (Brookes et al. 1985). The total C and $\mathrm{N}$ extracted after fumigation is considered representative of the active soil $\mathrm{C}$ and the plant-available $\mathrm{N}$ pools (Franzluebbers et al. 1999; Kristensen et al. 2003; Myrold 1987). The soil microbial biomass $N(M B N)$ has been suggested to be the main source of labile $\mathrm{N}$, which, upon release by tillage, may sustain soil fertility in agricultural systems (Kristensen et al. 2003). Tillage may substantially influence the distribution of $\mathrm{C}$ and $\mathrm{N}$ among different pools within agricultural soils (McCarty et al. 1995), likely influencing nutrient cycling within cropping systems. In addition, the soil microbial biomass $\mathrm{C}(\mathrm{MBC})$ and $\mathrm{MBN}$ respond rapidly to changes in management practices and can better reflect changes in soil quality and productivity that alter nutrient dynamics (Bremer and Van Kissel 1992; Saffigna et al. 1989; Sainju et al. 2013).

This research is part of a long-term effort to understand the effects of CsT on nutrient losses in the southeastern Coastal Plain. The objective of this study was to evaluate tillage impacts on soil $\mathrm{N}$ dynamics and $\mathrm{NO}_{3}^{-}-\mathrm{N}$ leaching losses related to different soil $\mathrm{C}$ and $\mathrm{N}$ pools under ST and CT practices. We hypothesized that soil available $\mathrm{N}$ and $\mathrm{NO}_{3}^{-}-\mathrm{N}$ leaching are primarily controlled by microbial $\mathrm{C}$ and $\mathrm{N}$ cycling in sandy soils of the southeastern Coastal Plain.

\section{Materials and Methods}

Site Description and Crop Management. The experiment was conducted between 2005 and 2010 at the University of Georgia Gibbs Research Farm in Tift County, Georgia (312' $\left.13^{\prime \prime} \mathrm{N}, 83^{\circ} 35^{\prime} 17^{\prime \prime} \mathrm{W}\right)$. The site, including a description of its soils, hydrology, and farming practices, has been described in detail (Bosch et al. 2005, 2012, 2015; Endale et al. 2014; Potter et al. 2014, 2015). In 1998, a $1.9 \mathrm{ha}(4.7 \mathrm{ac})$ parcel was divided into one 0.4 ha $(1 \mathrm{ac})$ and two 0.6 ha $(1.5 \mathrm{ac})$ treatment blocks (figure 1). The two 0.6 ha $(1.5$ ac) blocks were randomly assigned to either CT or ST management and further divided into three $0.2 \mathrm{ha}(0.5 \mathrm{ac})$ plots running across the slope. Plots 1,3 , and 5 were in continuous $\mathrm{CT}$, and plots 2, 4, and 6 were in ST (figure 1). Each year, the CT plots were plowed to 20 $\mathrm{cm}$ (8 in) approximately three weeks before planting, followed by disk harrowing to $8 \mathrm{~cm}$ (3 in) to form beds for planting. In the ST plots, an in-row shank subsoiler was used to create $15 \mathrm{~cm}$ (6 in) wide strips for planting with tillage to $20 \mathrm{~cm}$ ( 8 in). All plots were managed identically in a cotton (Gossypium hirsutum L.)-peanut (Arachis hypogea L.) rotation with cotton planted in 2005, 2007, and 2009 and peanut planted in 2004, 2006, and 2008 (table 1). After harvest, which typically occurred between September and October, the cotton and peanut residue was left on the soil surface in all the fields. A winter rye cover (Secale cereale L.) was planted after crop harvest in both CT and ST. The rye was killed each spring using glyphosate. Fertilization and pesticide treatment were identical for all plots and followed recommendations by the University of Georgia Extension. All plots received $4.5 \mathrm{Mg} \mathrm{ha}^{-1}$ (4,008 $\mathrm{lb} \mathrm{ac}^{-1}$ ) of poultry litter one month prior to planting in 2005 and 2007 (table 1). Additionally, starter fertilizer and side-dress fertilizer were applied during cotton production years and no additional fertilizer was applied during peanut years (table 1). Plant water needs were met from rainfall and a solid-set irrigation system. Irrigation measurements were collected directly from the fields using stationary rain gauges. Precipitation data were collected with a tipping bucket rain gauge

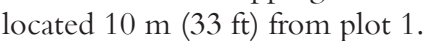

A detailed soil characterization at the site revealed the presence of a Carnegie sandy loam (fine, kaolinitic, thermic Plinthic Kandiudult) in plots 1 and 2, a Tifton loamy sand (fine-loamy, kaolinitic, thermic Plinthic Kandiudult) in plots 3 and 4, and a Fuquay loamy sand (loamy, kaolinitic, thermic arenic Plinthic Kandiudult) in plots 5 and 6 (Bosch et al. 2012). The presence of multiple soil series in fairly small areas is a common feature of the Coastal Plain, with each area of soil complex containing some of each of two or more dominant soils (Bosch et al. 2012). The surface soils are well drained, with a sandy loam or loamy sand horizon at the immediate surface extending to approximately $25 \mathrm{~cm}$ (10 in; Bosch et al. 2012). The soil series are characterized by an argillic horizon and plinthite below $50 \mathrm{~cm}$ (20 in) that controls internal drainage and promotes lateral subsurface flow (Bosch et al. 2012).

Experimental Protocol and Sample Collection. The experimental protocol followed the field component of the USDA Agricultural Research Service (ARS) multisite $\mathrm{N}$ mineralization study (Honeycutt et al. 2005; Hubbard et al. 2008). Microplot cylinders $(15.2 \mathrm{~cm}$ [6 in] long by $7.6 \mathrm{~cm}$ [3 in] diameter) made of Schedule 40 PVC pipe were initially installed in all the plots. Two cylinders were installed in each plot for a total of twelve cylinders (figure 1) that were driven into the soil with an impact hammer to minimize soil disturbance. The cylinders were carefully excavated from each site, and anion exchange resin beads (Anion Exchange Resin, IONAC A-554 $\mathrm{Cl}^{-}$Form, Type II, Beads [16-50 Mesh]) contained in nylon bags were placed at the bottom of each cylinder. The bags containing the resin beads were held in place at the bottom of each cylinder using plastic caps with drainage holes. The purpose of the anion resin beads was to capture $\mathrm{NO}_{3}^{-}-\mathrm{N}$ leaching through the soil. The cylinders were then returned to the same set of holes. Microplot cylinders were destructively sampled and new ones installed based on land management practices for the site (table 2).

Soil and Resin Bead Analysis. After collection, the resin bags were removed from the bottom of each cylinder and kept cool $\left(4^{\circ} \mathrm{C}\right.$ $\left.\left[39^{\circ} \mathrm{F}\right]\right)$ until analysis. The soil in each cylinder was removed, mixed, and sieved (3.35 $\mathrm{mm}[0.13 \mathrm{in}] \mathrm{mesh})$ to remove rocks and root material. Smaller rocks were removed by hand. The soil ( 20 g [0.7 oz], wet) was extracted by shaking for 60 minutes with $100 \mathrm{~mL}(0.2 \mathrm{pt})$ of $2 \mathrm{M} \mathrm{KCl}$. The extract was 


\section{Figure 1}

Layout of the study site illustrating the conventional tillage (CT; plots 1,3, and 5) and strip tillage (ST; plots 2, 4, and 6) treatments along with the upslope boundary plot (plot 7 ). The general cylinder locations are indicated by the dots. The location of the rain gauge is indicated by the black diamond. Elevation contours are in meters.

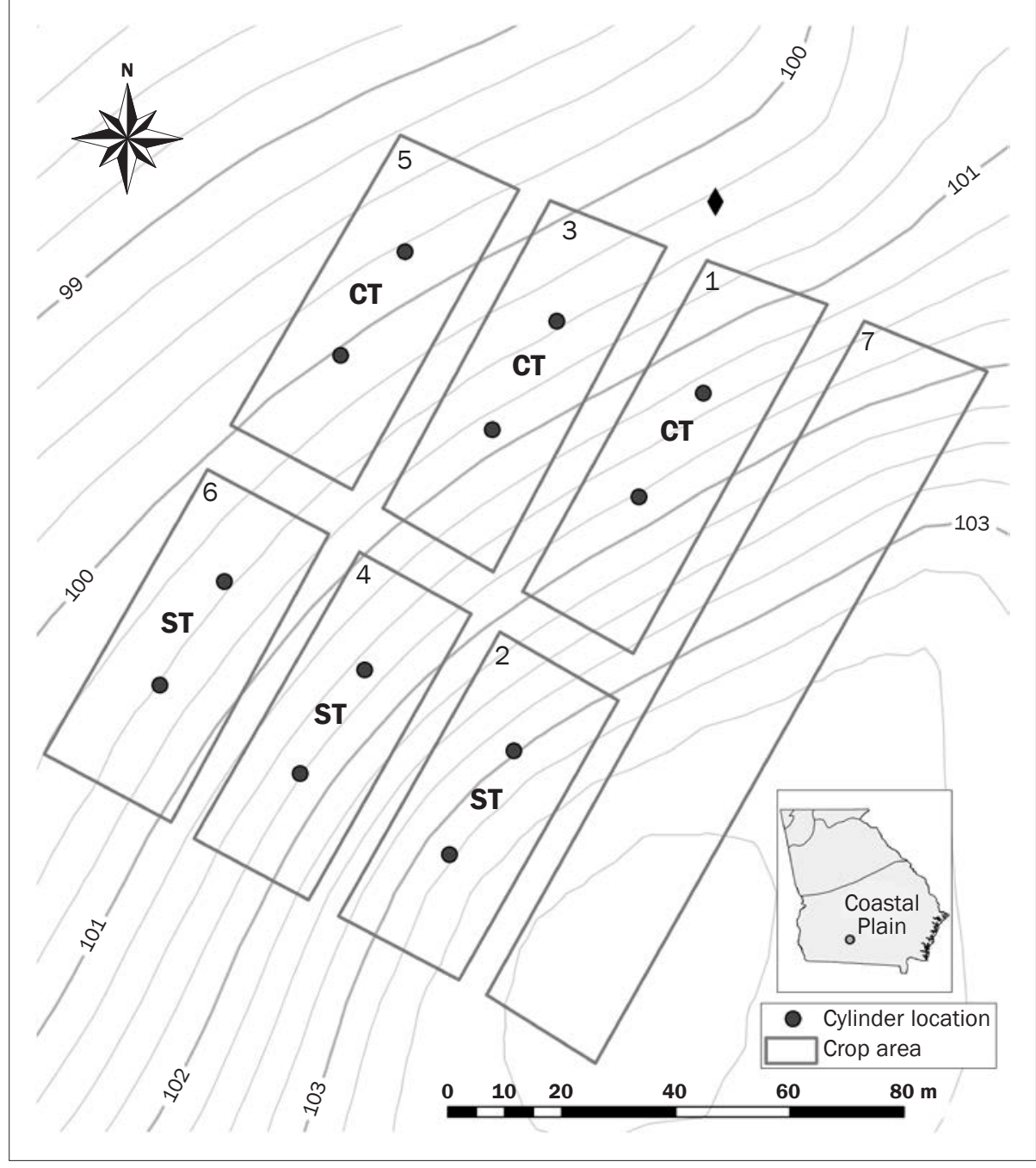

centrifuged and analyzed for $\mathrm{NH}_{4}^{+}-\mathrm{N}$ and $\mathrm{NO}_{3}^{-}-\mathrm{N}$ on a Lachat flow injection analyzer (QuikChem AE, Lachat Chemicals Inc., Milwaukee, Wisconsin) according to Lachat methods (12-107-06-2-A and 12-107-04$1-\mathrm{B}$, respectively). Method detection limits were 0.1 and $0.005 \mathrm{mg} \mathrm{L}^{-1}(0.00002$ and $0.000001 \mathrm{oz} \mathrm{gal}^{-1}$ ) for $\mathrm{NH}_{4}^{+}-\mathrm{N}^{-}$and $\mathrm{NO}_{3}{ }^{-} \mathrm{N}$, respectively. All samples were run in duplicate. Duplicate analyses that exceeded a $10 \%$ difference were reanalyzed. Midrange check standards were run after every 10 unknowns. If the check standard exceeded $10 \%$ of the expected value, the instrument was recalibrated. Blanks were run with each set of standards. Total C (TC) and N (TN) for the soils were determined on oven-dried and ball-milled samples ( 50 mg [0.0018 oz]) using a Carlo Erba NA 1500 series II C-N analyzer (CE Elantech, Lakewood, New Jersey) until 2006. This instrument was then replaced by a Vario EL III combustion $\mathrm{C}-\mathrm{N}$ analyzer (Elementar Analysensysteme GmbH, Germany). Total organic N (TON) was calculated by subtracting total inorganic $\mathrm{N}$ (TIN; $\mathrm{NH}_{4}^{+}+\mathrm{NO}_{3}^{-}$) from $\mathrm{TN}$.

The resin bags were cut open and the contents were poured into a $1 \mathrm{~L}(2.11 \mathrm{pt})$ Erlenmeyer flask. The resin bag was turned inside out over a funnel and the remaining resin beads were brushed into the same flask. The resin beads were extracted by shaking with $250 \mathrm{~mL}(0.52 \mathrm{pt})$ of $2 \mathrm{M}$ potassium chloride $(\mathrm{KCl})$ for 60 minutes. The extract was centrifuged and analyzed for $\mathrm{NO}_{3}^{-}-\mathrm{N}$ following the same procedure and quality control used for the soil extracts. Because the beads were composed of an anion exchange resin, these extracts were only analyzed for $\mathrm{NO}_{3}^{-}-\mathrm{N}$ (Honeycutt et al. 2005).

Soil Microbial Biomass Analysis. Soil microbial biomass was estimated using a modification of the chloroform fumigation-extraction procedure (Brookes et al. 1985). Three soil subsamples ( 20 g [0.7 $\mathrm{oz}]$ ) were extracted with $100 \mathrm{~mL}(0.21 \mathrm{pt})$ aqueous $0.5 \mathrm{M}$ potassium sulfate $\left(\mathrm{K}_{2} \mathrm{SO}_{4}\right)$ by shaking for 60 minutes on a reciprocal shaker at $180 \mathrm{rpm}$. The extracts were passed through a $0.7 \mu \mathrm{m}$ GF/F filter (Whatman) and analyzed only for TC on a Shimadzu 5000 TOC analyzer until 2007. The Shimadzu 5000 was then replaced with a Shimadzu TOC-VCPN analyzer with an ASI-V autosampler and a TNM-1 N module (Shimadzu Scientific Instruments, Columbia, Maryland), which was used to measure TC and TN on the extracts obtained after 2007. Three additional soil subsamples were transferred to a scintillation vial to which $100 \mu \mathrm{L}$ ethanol-free chloroform was added. To ensure even chloroform distribution throughout the sample, the vials were placed in a vacuum dessicator with moist paper towels and a beaker containing $50 \mathrm{~mL}(0.1 \mathrm{pt})$ of ethanol-free chloroform. The dessicator was evacuated three times to create a chloroform atmosphere and closed after the third evacuation. Samples were kept in the dessicator for seven days at room temperature. The samples were then washed with aqueous $0.5 \mathrm{M} \mathrm{K}_{2} \mathrm{SO}_{4}$, extracted, and analyzed for TC and TN as above. The MBC and $\mathrm{MBN}$ were calculated as the difference in the mass of $\mathrm{C}$ or $\mathrm{N}$ extracted from the soil with and without fumigation. Chloroform fumigated extracted concentrations $\left(\mathrm{g}^{-1}\right.$ soil) were multiplied by the soil bulk density and taken as an estimate of potentially mineralizable C and N (Franzluebbers et al. 1999). The mean values of soil triplicate subsamples were taken as individual values for each core for data analyses.

Data Analysis. The total water input to the field was obtained by adding the precipitation and irrigation data for the time the cylinder was in the soil (table 2). Statistical comparisons were made by tillage treatment, cylinder sampling date, and by year. Data sets were tested for normality using the ShapiroWilk normality test. Nonnormal nonpaired data sets were tested using the Mann-Whitney two-tailed nonparametric test. Normal data 
sets were tested using a two-tailed paired $t$-test. All statistical tests were considered significant at $p \leq 0.05$. Statistical analyses were made using SigmaPlot (version 13.0).

\section{Results and Discussion}

Soil Nitrogen and Carbon Dynamics. Soil chemical characteristics are summarized in tables 3 and 4 . On both a seasonal and an annual basis, the TC was typically higher in the ST plots, although these differences were statistically significant $(p \leq 0.05)$ only for some of the cylinder extraction dates (table 3) and all but one of the annual averages (2008; table 4). Similar results were observed for TN except that annual values were significantly different only in 2007 and 2009. Conservation practices, including ST, can result in increases in soil $\mathrm{C}$ and $\mathrm{N}$ storage (Al-Kaisi et al. 2005; Halvorson et al. 2002; Lal et al. 2007). Conventional tillage produces greater areas of soil disturbance and mixing than ST, resulting in lower soil C and $\mathrm{N}$ content due to increased soil aeration, aggregate disruption, and organic matter mineralization (Halvorson et al. 2002; West and Post 2002). In a study of Tifton sandy soils, five years of winter cover cropping and ST increased soil C in the top $35 \mathrm{~cm}$ (14 in) by up to $80 \%$ (Strickland et al. 2015). In the present study, TC and TN increased throughout the five-year study period for both tillage treatments (table 4), suggesting that winter cover cropping is improving soil quality (Dabney et al. 2001). The five-year TC and TN averages were higher in ST, indicating the preferential accumulation of TC and TN with ST practices. Higher TN values with $\mathrm{ST}$ compared to CT resulted in lower $\mathrm{C}: \mathrm{N}$ ratios in the former (tables 3 and 4). The $\mathrm{C}: \mathrm{N}$ ratio is a good indicator of the degree of availability, decomposition, and overall quality of SOM (Batjes 1996). A decrease in the $\mathrm{C}: \mathrm{N}$ ratio reflects a greater degree of SOM breakdown and may be associated with a higher abundance of microbial biomass in the ST plots (discussed below). Here, the C:N ratios were stable over time for both treatments, indicating a direct linkage in the sources and decomposition stage of the soil TC and TN pools.

Ammonium-N and $\mathrm{NO}_{3}^{-}-\mathrm{N}$ were small components of the soil $\mathrm{N}$ pool, which was dominated by TON (tables 3 and 4). The inorganic $\mathrm{N}$ species $\left(\mathrm{NH}_{4}^{+}-\mathrm{N}\right.$ and $\mathrm{NO}_{3}{ }^{-} \mathrm{N}$ ) were typically higher in $\mathrm{ST}^{4}$ compared to $\mathrm{CT}$ plots on both a seasonal (table 3) and annual
Table 1

Crop rotation, fertilizations, and fertilizer nitrogen $(\mathrm{N})$ content $\left(\mathrm{kg} \mathrm{ha}^{-1}\right)$ applied to the Gibbs Farm plots during the study period.

\begin{tabular}{llr}
\hline Treatment date & Treatment description & N (kg ha $\mathbf{~}^{\mathbf{1}}$ ) \\
\hline $\begin{array}{l}\text { May 10, 2004 } \\
\text { October 5, 2004 }\end{array}$ & Planted peanuts & \\
Year total & Planted winter cover, rye and crimson clover mix & 0.0 \\
\hline April 19, 2005 & Applied poultry litter & 121.4 \\
May 23, 2005 & Planted cotton & \\
May 23, 2005 & Applied starter liquid fertilizer & 17.3 \\
June 22, 2005 & Applied granular fertilizer & 45.3 \\
June 27, 2005 & Applied granular fertilizer & 45.3 \\
November 16, 2005 & Planted winter cover, rye & \\
Year total & & 229.3 \\
\hline May 9, 2006 & Planted peanuts & \\
October 31, 2006 & Planted winter cover, rye & 0.0 \\
Year total & & 139.8 \\
\hline April 17, 2007 & Applied poultry litter & 17.4 \\
May 1, 2007 & Planted cotton & 47.0 \\
May 1, 2007 & Applied starter liquid fertilizer & \\
June 7, 2007 & Applied liquid fertilizer & 106.4 \\
October 15, 2007 & Planted winter cover, rye & 204.2 \\
Year total & & \\
\hline May 20, 2008 & Planted peanuts & \\
October 29, 2008 & Planted winter cover, rye & \\
Year total & & \\
\hline April 21, 2009 & Applied granular fertilizer & \\
May 4, 2009 & Planted cotton & \\
November 4, 2009 & Planted winter cover, rye and Austrian winter pea mix & \\
June 19, 2009 & Applied sidedress liquid fertilizer \\
November 5, 2009 & Applied granular fertilizer & \\
Year total & & \\
& & \\
\hline
\end{tabular}

\section{Table 2}

Cylinder group installation and collection dates, days in situ, and total precipitation plus irrigation $(\mathrm{mm})$ for that period. Each cylinder group consisted of six cylinders in conventional and six cylinders in strip tillage treatments.

\begin{tabular}{lllcc}
\hline $\begin{array}{l}\text { Cylinder } \\
\text { group }\end{array}$ & Date installed & Date collected & $\begin{array}{l}\text { Days } \\
\text { in situ }\end{array}$ & $\begin{array}{c}\text { Precipitation + } \\
\text { irrigation }(\mathbf{m m})\end{array}$ \\
\hline 1 & October 8, 2004 & January 12, 2005 & 85 & 170 \\
2 & January 12, 2005 & April 13, 2005 & 91 & 461 \\
3 & May 26, 2005 & August 9, 2005 & 75 & 589 \\
4 & August 9, 2005 & September 22, 2005 & 44 & 85 \\
5 & December 1, 2005 & March 1, 2006 & 90 & 386 \\
6 & March 1, 2006 & April 3, 2006 & 33 & 25 \\
7 & May 25, 2006 & August 28, 2006 & 95 & 421 \\
8 & November 13, 2006 & February 12, 2007 & 91 & 336 \\
9 & February 13, 2007 & April 17, 2007 & 63 & 88 \\
10 & May 7, 2007 & August 13, 2007 & 98 & 380 \\
11 & October 30, 2007 & January 30, 2008 & 92 & 271 \\
12 & January 30, 2008 & March 17, 2008 & 47 & 286 \\
13 & May 23, 2008 & September 2, 2008 & 102 & 614 \\
14 & November 19, 2008 & February 10, 2009 & 83 & 213 \\
15 & May 14, 2009 & August 26, 2009 & 104 & 496 \\
16 & November 9, 2009 & March 1, 2010 & 112 & 482 \\
& & & &
\end{tabular}




\section{Table 3}

Seasonal soil chemistry parameters, including total carbon (TC) and nitrogen (TN), carbon to nitrogen ratios (C:N), ammonium-N (NH ${ }_{4}^{+}-\mathrm{N}^{2}$, nitrate- $\mathrm{N}$ $\left(\mathrm{NO}_{3}{ }^{-} \mathrm{N}\right)$, and total inorganic (TIN) and total organic $\mathrm{N}$ (TON) for the soil cylinders. Values are averages \pm standard error $(n=6)$, and bold font indicates a significant difference $(p \leq 0.05)$ between conventional (CT) and strip tillage (ST) for a particular cylinder collection date.

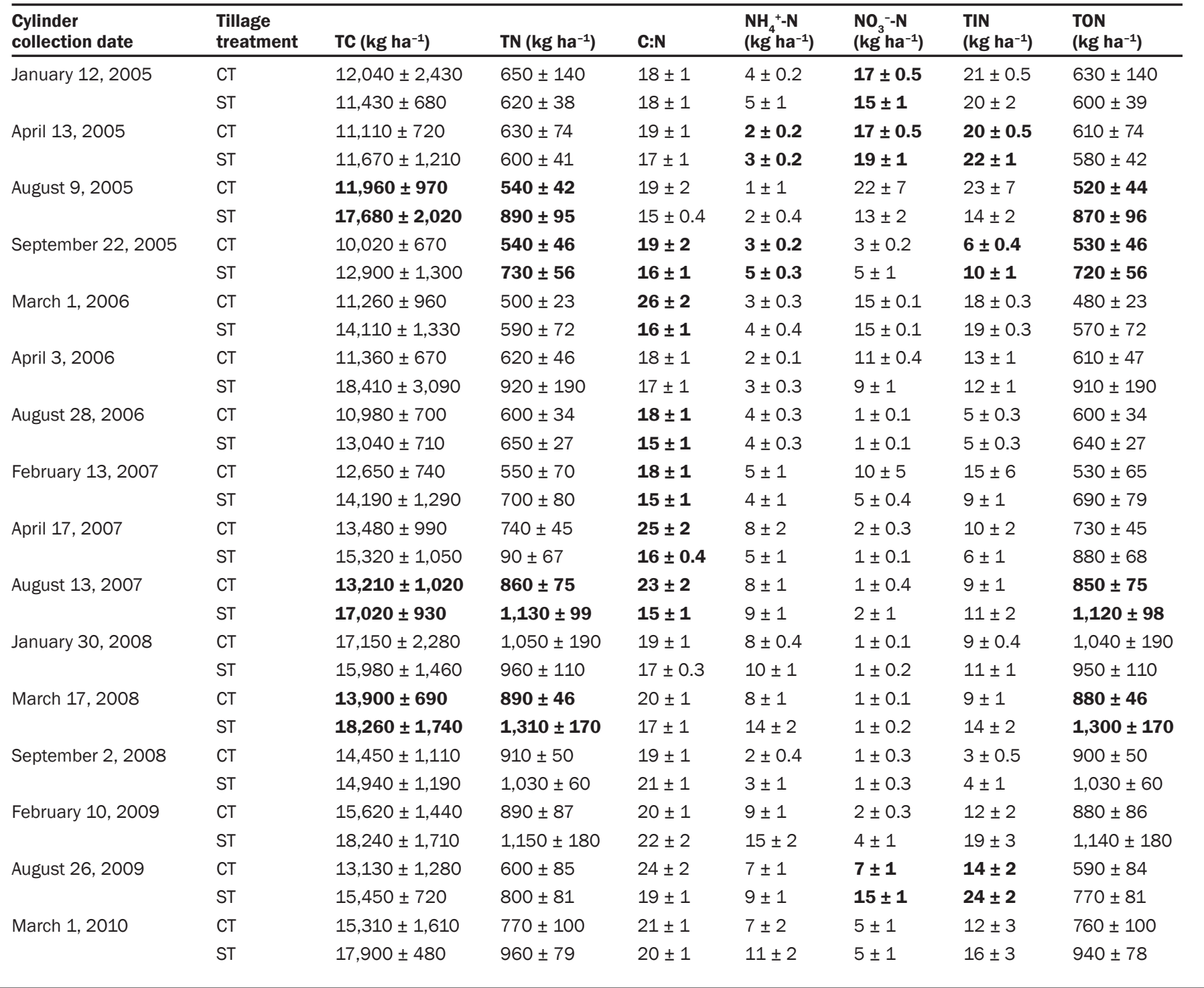

basis (table 4). No trends were observed in the concentration of $\mathrm{NH}_{4}^{+}-\mathrm{N}$ in the individual soil cylinders throughout the study period (table 3). However, on an annual basis, significantly higher $\mathrm{NH}_{4}^{+}-\mathrm{N}$ values with ST were observed in all but two years (table 4). The soil $\mathrm{NH}_{4}^{+}-\mathrm{N}$ content was significantly higher $(p \leq 0.05)$ at the end of the five-year study period with highest values observed in 2009 for both CT and ST. The amount of fertilizer $\mathrm{N}$ applied in 2009 was lower compared to that applied in 2005 and 2007 (table 1). It may be possible that the high TC, TN, and TON contents also observed in 2009 (table 4) may have been available to generate $\mathrm{NH}_{4}^{+}-\mathrm{N}$ due to a more active microbial turnover of available SOM. The five-year $\mathrm{NH}_{4}^{+}-\mathrm{N}$ soil content average was significantly higher in the ST plots $(p \leq 0.05)$ and was higher than five-year averages previously reported for surface and subsurface loads measured in the same plots under both tillage treatments (Bosch et al. 2015). The higher $\mathrm{NH}_{4}^{+}-\mathrm{N}$ soil content in ST may be associated with higher amounts of MBN with this management practice (discussed below).

The soil $\mathrm{NO}_{3}^{-}-\mathrm{N}$ content did not show any trends with cylinder extraction dates (table 3), likely due to the fact that $\mathrm{NO}_{3}{ }^{-} \mathrm{N}$ is readily leached (Di and Cameron 2002). The low $\mathrm{NO}_{3}^{-}-\mathrm{N}$ concentrations occurring from August of 2006 to the end of the study period with both CT and ST treatments may have resulted from low fertilization after this time (table 1). High microbial biomass was observed during periods of low $\mathrm{NO}_{3}^{-}-\mathrm{N}$ and high TON, in particular for the soil cylinders sampled from August of 2007 (after the addition of poultry litter; table 1) through February of 2009. The soil $\mathrm{NO}_{3}^{-}-\mathrm{N}$ concentration was highest in 2005 for both CT and $\mathrm{ST}$, although significant differences between the two tillage practices were observed only in 2009 (table 4). Elevated $\mathrm{NO}_{3}^{-}-\mathrm{N}$ loads have been reported in surface runoff from the same plots in 2005 and were attributed to higher surface runoff observed that year (Bosch et al. 2015). In the present study, 


\section{Table 4}

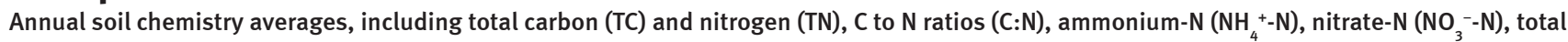
inorganic N (TIN), and total organic N (TON) for the soil cylinders. Values are averages \pm standard error. Bold font indicates a significant difference $(p \leq 0.05)$ between conventional (CT) and strip tillage (ST) for a particular year. Values within a treatment row followed by different lowercase letters are significantly different $(p \leq 0.05)$ between years.

\begin{tabular}{|c|c|c|c|c|c|c|c|}
\hline Parameter & $\begin{array}{l}\text { Tillage } \\
\text { treatment }\end{array}$ & $2005(n=24)$ & $2006(n=18)$ & $2007(n=18)$ & $2008(n=18)$ & $2009\left(n=18^{*}\right)$ & $\begin{array}{l}\text { Five-year } \\
\text { average }(n=96)\end{array}$ \\
\hline \multirow[t]{2}{*}{ TC $\left(\mathrm{kg} \mathrm{ha}^{-1}\right)$} & CT & $11,280 \pm 670 a$ & $11,200 \pm 430 a$ & $13,110 \pm 510 b$ & $15,170 \pm 890 b$ & $14,680 \pm 830 b$ & $12,980 \pm 350$ \\
\hline & ST & $13,420 \pm 830 a$ & $15,190 \pm 1,220 a b$ & $15,510 \pm 660 b$ & $16,400 \pm 870 b$ & $17,190 \pm 670 b$ & $15,410 \pm 410$ \\
\hline \multirow[t]{2}{*}{ TN $\left(\mathrm{kg} \mathrm{ha}^{-1}\right)$} & CT & $590 \pm 40 a$ & $570 \pm 24 a$ & $720 \pm 47 b$ & $950 \pm 67 c$ & $760 \pm 58 b$ & $710 \pm 25$ \\
\hline & ST & $710 \pm 37 a$ & $720 \pm 74 a$ & $910 \pm 62 b$ & $1,100 \pm 76 b$ & $970 \pm 76 b$ & $870 \pm 32$ \\
\hline \multirow[t]{2}{*}{$\mathrm{C}: \mathrm{N}$} & CT & $19 \pm 1 a$ & $20 \pm 1 a b$ & $22 \pm 1 a b$ & $19 \pm 1 a b$ & $22 \pm 1 b$ & $20 \pm 0.4$ \\
\hline & ST & $17 \pm 0.5 a$ & $16 \pm 0.4 a$ & $15 \pm 0.3 b$ & $18 \pm 1 c$ & $21 \pm 1 c$ & $17 \pm 0.3$ \\
\hline \multirow[t]{2}{*}{$\mathrm{NH}_{4}^{+}-\mathrm{N}\left(\mathrm{kg} \mathrm{ha}^{-1}\right)$} & $\mathrm{CT}$ & $3 \pm 0.3 a$ & $3 \pm 0.3 a$ & $7 \pm 1 b$ & $6 \pm 1 b$ & $8 \pm 1 b$ & $5 \pm 0.3$ \\
\hline & ST & $4 \pm 0.4 a$ & $4 \pm 0.2 a$ & $6 \pm 1 b$ & $9 \pm 1 b$ & $12 \pm 1 c$ & $7 \pm 0.5$ \\
\hline \multirow[t]{2}{*}{$\mathrm{NO}_{3}{ }^{-}-\mathrm{N}\left(\mathrm{kg} \mathrm{ha}^{-1}\right)$} & $\mathrm{CT}$ & $15 \pm 2 a$ & $9 \pm 1 b$ & $4 \pm 2 c$ & $1 \pm 0.1 d$ & $5 \pm 1 c$ & $7 \pm 1$ \\
\hline & ST & $13 \pm 1 a$ & $8 \pm 1 b$ & $3 \pm 0.5 c$ & $1 \pm 0.1 d$ & $8 \pm 1 b$ & $7 \pm 1$ \\
\hline \multirow[t]{2}{*}{ TIN $\left(\mathrm{kg} \mathrm{ha}^{-1}\right)$} & $\mathrm{CT}$ & $17 \pm 2 a$ & $12 \pm 1 b$ & $11 \pm 2 b$ & $7 \pm 1 c$ & $12 \pm 1 b$ & $12 \pm 1$ \\
\hline & ST & $17 \pm 1 a$ & $12 \pm 1 b$ & $9 \pm 1 b$ & $10 \pm 1 b$ & $20 \pm 2 a$ & $14 \pm 1$ \\
\hline \multirow[t]{2}{*}{ TON (kg ha-1) } & CT & $570 \pm 40 a$ & $560 \pm 24 a$ & $710 \pm 47 b$ & $940 \pm 66 c$ & $740 \pm 58 b$ & $700 \pm 26$ \\
\hline & ST & $690 \pm 38 a$ & $710 \pm 74 a$ & $900 \pm 62 b$ & $1,090 \pm 75 b$ & $950 \pm 76 b$ & $860 \pm 32$ \\
\hline
\end{tabular}

*The final cylinder was collected at the beginning of March of 2010 and was included in the 2009 annual average for a better estimation of significant differences between tillage treatments in that year.

elevated $\mathrm{NO}_{3}^{-}-\mathrm{N}$ concentrations may have resulted from the application of fertilizer in 2005 (table 1). However, comparable $\mathrm{NO}_{3}^{-}-\mathrm{N}$ values were not observed in 2007 or in 2009 when fertilizer was also applied, suggesting other reasons for elevated concentrations, such as high internal production (soil microbial nitrification) using $\mathrm{NH}_{4}^{+}$or TON as substrates. In fact, the yearly average of both $\mathrm{NH}_{4}^{+}$and TON was lower in 2005 compared to 2007 and 2009 (table 4).

Seasonal and Cumulative Differences in Nitrate Leaching. Nitrate leaching occurs when there is an accumulation of $\mathrm{NO}_{3}^{-}$in the soil profile that coincides with, or is followed by, a period of high drainage (Di and Cameron 2002). The $\mathrm{NO}_{3}^{-}$may come from the $\mathrm{N}$ applied in the form of fertilizer or effluents, or from the mineralization of soil organic N. In this study, the highest concentration of leached $\mathrm{NO}_{3}{ }^{-}-\mathrm{N}$ was measured from the soil cylinders collected in August of 2005 and 2007, regardless of tillage treatment (table 5). These high $\mathrm{NO}_{3}^{-}-\mathrm{N}$ values coincide with the application of poultry litter in April and subsequent fertilization in those two years (table 1). The cumulative $\mathrm{N}$ added as poultry litter and fertilizer was 229.3 and $204.2 \mathrm{~kg} \mathrm{~N} \mathrm{ha}^{-1}$ (204 and $182 \mathrm{lb} \mathrm{N} \mathrm{ac}^{-1}$ ) in 2005 and 2007 (table 1), respectively, which are typical values of application to meet crop $\mathrm{N}$ demand (Di and Cameron 2002). Because $\mathrm{N}$ fertilization is typically applied in the fast growing season of the year and is rapidly taken up by the crop, the chances of the fertilizer $\mathrm{N}$ to be leached during the growing season are usually low, unless the application rates are excessively high and there is a high water input. In this study, plant $\mathrm{N}$ uptake was not measured because the cylinders excluded plant biomass. However, these results suggest that fertilizer application and soil microbial activity may potentially be important factors for $\mathrm{NO}_{3}^{-}-\mathrm{N}$ leaching in sandy soils. Although elevated $\mathrm{NO}_{3}^{-}-\mathrm{N}$ concentrations have been found in Tifton soils amended with poultry litter (Hubbard et al. 2008), we observed no significant differences in the amount of leached $\mathrm{NO}_{3}^{-}-\mathrm{N}$ between $\mathrm{CT}$ and ST treatments for individual cylinder collection dates (table 5).

The annual average leached $\mathrm{NO}_{3}^{-}-\mathrm{N}$ aggregated by treatment showed significant differences between years (table 5). Under both CT and ST, the highest amount of leached $\mathrm{NO}_{3}^{-}-\mathrm{N}$ was observed in 2007, following the application of poultry litter and fertilizer (table 1). However, a relationship between the annual average $\mathrm{NO}_{3}^{-}-\mathrm{N}$ leached and fertilizer application was not observed in 2005 and 2009, suggesting that leaching may depend more on microbial $\mathrm{N}$ processing in the top $15 \mathrm{~cm}$ (6 in) of soil (Di and Cameron 2002; Herai et al. 2006). In addition, no relationship was observed between the amount of leached $\mathrm{NO}_{3}^{-}-\mathrm{N}$ and the yearly total pre- cipitation plus irrigation. Finally, the five-year average $\mathrm{NO}_{3}^{-}-\mathrm{N}$ leached was not significantly different between CT and ST (table 5).

The cumulative, five-year load of $\mathrm{NO}_{3}{ }^{-} \mathrm{N}$ leached from the soils was higher in CT (141 $\left.\mathrm{kg} \mathrm{ha}^{-1}\left[126 \mathrm{lb} \mathrm{ac}^{-1}\right]\right)$ compared to ST $(122 \mathrm{~kg}$ $\mathrm{ha}^{-1}\left[109 \mathrm{lb} \mathrm{ac}^{-1}\right.$; figure 2), although these differences were not statistically significant. The lower cumulative leached $\mathrm{NO}_{3}^{-}-\mathrm{N}$ load with ST suggests enhanced microbial $\mathrm{N}$ processing with this tillage treatment (Causarano et al. 2008). In fact, the five-year average microbial biomass was higher in ST compared to CT (discussed below). The largest increase in the cumulative leached $\mathrm{NO}_{3}^{-}-\mathrm{N}$ occurred in 2005 and 2007, after the application of poultry litter (figure 2). From 2005 to 2007, the cumulative $\mathrm{NO}_{3}^{-}-\mathrm{N}$ leached from the soils was higher in ST compared to CT. However, from 2007 to the end of the study period the cumulative $\mathrm{NO}_{3}^{-}-\mathrm{N}$ leached from the soils was higher in CT. Because our experimental design did not include measurements of $\mathrm{N}$ uptake by plants, the measured cumulative $\mathrm{NO}_{3}{ }^{-}-\mathrm{N}$ leached from soil represents an overestimation of $\mathrm{N}$ loss. Nonetheless, our five-year $\mathrm{NO}_{3}^{-}-\mathrm{N}$ leaching results are higher than those reported for five-year $\mathrm{N}$ loads $\left(\mathrm{NH}_{4}^{+}\right.$and $\left.\mathrm{NO}_{3}^{-}\right)$in surface and subsurface runoff for the same time period at this site (Bosch et al. 2015). These authors reported that subsurface flow (measured at $1.2 \mathrm{~m}[4 \mathrm{ft}]$ depth) was the primary hydrologic pathway 


\section{Table 5}

Seasonal values and annual averages of leached nitrate-nitrogen $\left(\mathrm{NO}_{3}{ }^{-}-\mathrm{N}\right)$ from the soil cylinders. Seasonal values are averages \pm standard error $(n=6)$. Bold font indicates a significant difference $(p \leq 0.05)$ between conventional and strip tillage for a particular cylinder collection date. Significant differences in within treatment annual averages are indicated by different lowercase letters.

\begin{tabular}{|c|c|c|}
\hline Cylinder collection date & $\begin{array}{l}\text { Conventional tillage } \\
\text { leached } \mathrm{NO}_{3}^{-}-\mathrm{N}\left(\mathrm{kg} \mathrm{ha}^{-1}\right) \\
\end{array}$ & $\begin{array}{l}\text { Strip tillage leached } \\
\mathrm{NO}_{3}^{-}-\mathrm{N}\left(\mathrm{kg} \mathrm{ha}^{-1}\right)\end{array}$ \\
\hline January 12, 2005 & $3.28 \pm 1.04$ & $2.70 \pm 1.19$ \\
\hline April 13, 2005 & $2.15 \pm 0.47$ & $1.83 \pm 0.69$ \\
\hline August 9, 2005 & $28.63 \pm 5.32$ & $35.01 \pm 3.03$ \\
\hline September 22, 2005 & $1.26 \pm 0.57$ & $1.15 \pm 0.46$ \\
\hline 2005 average $(n=24)$ & $8.83 \pm 2.71 a$ & $10.17 \pm 3.09 a$ \\
\hline March 1, 2006 & $2.47 \pm 0.53$ & $4.67 \pm 1.27$ \\
\hline April 3, 2006 & $0.10 \pm 0.01$ & $0.14 \pm 0.03$ \\
\hline August 28, 2006 & $6.57 \pm 0.54$ & $4.10 \pm 0.47$ \\
\hline 2006 average $(n=18)$ & $3.05 \pm 0.69 b$ & $2.97 \pm 0.65 b$ \\
\hline February 13, 2007 & $3.05 \pm 0.64$ & $2.84 \pm 0.71$ \\
\hline April 17, 2007 & $0.49 \pm 0.10$ & $0.52 \pm 0.12$ \\
\hline August 13, 2007 & $57.19 \pm 25.82$ & $33.83 \pm 23.62$ \\
\hline 2007 average $(n=18)$ & $20.24 \pm 10.28 c$ & $12.40 \pm 8.26 c$ \\
\hline January 30, 2008 & $6.74 \pm 0.38$ & $7.51 \pm 0.50$ \\
\hline March 17, 2008 & $6.72 \pm 0.17$ & $7.70 \pm 0.74$ \\
\hline September 2, 2008 & $13.08 \pm 1.62$ & $9.61 \pm 0.95$ \\
\hline 2008 average $(n=18)$ & $8.85 \pm 0.90 \mathrm{~d}$ & $8.27 \pm 0.47 d$ \\
\hline February 10, 2009 & $0.78 \pm 0.44$ & $1.62 \pm 0.73$ \\
\hline August 26, 2009 & $3.62 \pm 0.80$ & $3.77 \pm 0.74$ \\
\hline March 1, 2010 & $4.45 \pm 0.79$ & $4.92 \pm 0.25$ \\
\hline 2009 average $(n=18 *)$ & $2.95 \pm 0.54 d$ & $3.43 \pm 0.47 \mathrm{e}$ \\
\hline Five-year average $(n=96)$ & $8.79 \pm 2.10$ & $7.62 \pm 1.74$ \\
\hline
\end{tabular}

*The final cylinder was collected at the beginning of March of 2010 and was included in the 2009 annual average for a better estimation of significant differences between tillage treatments in that year.

for dissolved $\mathrm{N}$ loss in both tillage systems with a total five-year load of $45 \mathrm{~kg} \mathrm{~N} \mathrm{ha}^{-1}$ $\left(40 \mathrm{lb} \mathrm{N} \mathrm{ac}{ }^{-1}\right)$ and $99 \mathrm{~kg} \mathrm{~N} \mathrm{ha}^{-1}\left(88 \mathrm{lb} \mathrm{N} \mathrm{ac}^{-1}\right)$ lost from CT and ST plots, respectively. The higher $\mathrm{N}$ losses in ST plots were attributed to the dominance of subsurface water loss with this tillage treatment. Much lower fiveyear $\mathrm{N}$ loads were reported in surface runoff (8.3 and $5.6 \mathrm{~kg} \mathrm{~N} \mathrm{ha}^{-1}\left[7\right.$ and $5 \mathrm{lb} \mathrm{N} \mathrm{ac}{ }^{-1}$ ] in $\mathrm{CT}$ and ST, respectively). Studies performed at the watershed scale in this same area reported an average annual $\mathrm{N}$ loss of 0.58 to $0.94 \mathrm{~kg} \mathrm{~N} \mathrm{ha}^{-1}$ (0.5 to $0.8 \mathrm{lb} \mathrm{N} \mathrm{ac}^{-1}$; Feyereisen et al. 2008), with such low values attributed to vegetative filtering by riparian buffers (Hubbard and Lowrance 1996). Additionally, $\mathrm{N}$ is removed from croplands during harvest through biomass removal. Data from these same plots indicate that the total $\mathrm{N}$ removed in a peanut year is $\sim 52$ $\mathrm{kg} \mathrm{N} \mathrm{ha}{ }^{-1}$ (46 $\mathrm{lb} \mathrm{N} \mathrm{ac}^{-1}$ ) and that the total $\mathrm{N}$ removed in a cotton year (through the removal of cotton lint and seeds) is $\sim 87 \mathrm{~kg}$
$\mathrm{N} \mathrm{ha}^{-1}$ (77 lb N ac${ }^{-1}$; Strickland, unpublished data, 2013 and 2014). A comparison of fiveyear averages for the different pathways of $\mathrm{N}$ loss in the southeastern Coastal Plain (leaching, 122 to $141 \mathrm{~kg} \mathrm{ha}^{-1}$ [109 to $126 \mathrm{lb} \mathrm{ac}^{-1}$ ]; surface runoff, 6 to $8 \mathrm{~kg} \mathrm{ha}^{-1}$ [5.3 to $7 \mathrm{lb} \mathrm{ac}^{-1}$ ]; subsurface flow, 45 to $99 \mathrm{~kg} \mathrm{ha}^{-1}$ [40 to $88 \mathrm{lb}$ $\mathrm{ac}^{-1}$; losses from the watershed, $\sim 5 \mathrm{~kg} \mathrm{ha}^{-1}$ [4.4 $\left.\mathrm{lb} \mathrm{ac}^{-1}\right]$; and crop harvest, 259 and 437 $\mathrm{kg} \mathrm{ha}^{-1}$ [231 and $390 \mathrm{lb} \mathrm{ac}^{-1}$ ] for peanuts and cotton, respectively) indicates that $\mathrm{NO}_{3}^{-}-\mathrm{N}$ leaching from the top $15 \mathrm{~cm}$ (6 in) of soil is an important pathway of $\mathrm{N}$ loss from the rooting zone regardless of tillage treatment However, it appears that substantial $\mathrm{N}$ sinks ( $\geq 27$ to $31 \mathrm{~kg} \mathrm{ha}^{-1} \mathrm{y}^{-1}$ [24 to $\left.27.6 \mathrm{lb} \mathrm{ac}^{-1} \mathrm{yr}^{-1}\right]$ ) are also active in this system that recapture $\mathrm{N}$ lost via leaching. This estimate includes the approximately $2.6 \mathrm{~kg} \mathrm{ha}^{-1} \mathrm{y}^{-1}\left(2 \mathrm{lb} \mathrm{ac}^{-1}\right.$ $\mathrm{yr}^{-1}$ ) on $\mathrm{N}$ input via atmospheric deposition (NADP 2013).

Changes in Soil Microbial Biomass with Conventional and Strip Tillage. Soil micro- bial biomass is an important component of soil quality because of its role in nutrient dynamics (Franzluebbers et al. 1999; Harris et al. 1997). Soil MBC and MBN are considered part of the active fraction of SOM, important for supplying plant nutrients, decomposing organic residues, and developing soil structure (Franzluebbers et al. 2000; McCarty et al. 1995). The MBC and MBN are responsive to soil management and typically increase with residue incorporation into the soil due to increased tillage (Franzluebbers et al. 2000; McCarty et al. 1995; Sainju et al. 2013). In the current study, although MBC was higher with ST only for three of the sampling dates (table 6), over the five-year study it was $28 \mathrm{~kg}$ $\mathrm{ha}^{-1}\left(25 \mathrm{lb} \mathrm{ac}^{-1}\right)$ higher than CT (table 7) as has been reported by others for surface soils of the southeastern Coastal Plain (Causarano et al. 2008).

Chloroform fumigation increased the amount of total $\mathrm{N}$ extracted by $0.5 \mathrm{M} \mathrm{K}_{2} \mathrm{SO}_{4}$ from all the soils (table 6). This soluble and labile $\mathrm{N}$ pool did not show any clear seasonal trends and was significantly higher in ST compared to CT only for one sampling date (August of 2009; table 6). On an annual basis, this soluble and labile $\mathrm{N}$ fraction was significantly higher in ST compared to CT only in 2009, and there was no significant difference between tillage treatments in the overall five-year average (table 7). Although there were no clear patterns in the amount of soil $\mathrm{N}$ extracted following chloroform fumigation, the amount extracted was significantly correlated with the soil TN and TON contents only with the ST treatment $\left(R^{2}\right.$ $=0.5382$ and $0.5374, p \leq 0.05)$, suggesting that available $\mathrm{N}$ is an important component of the total $\mathrm{N}$ pool with this management practice. The MBN values indicate that the majority of the soil extractable $\mathrm{N}$ is part of the microbial biomass (tables 6 and 7). Based on cylinder extraction dates, there were no significant differences in $\mathrm{MBN}$ between the tillage treatments (table 6). However, the fiveyear MBN average was significantly higher for ST compared to CT (table 7). In addition, soil MBN was significantly correlated to the soil TN only with ST $\left(R^{2}=0.5668\right.$, $p \leq 0.05)$. Although $\mathrm{MBN}$ represents a small percentage of the soil TON (up to $6 \%$ and $9 \%$ for ST and CT, respectively), it appears to cycle $\mathrm{N}$ in the rooting zone, thus slowly releasing plant available $\mathrm{N}$ in the rooting zone and potentially sustaining plant productivity. Without this retention mechanism, 


\section{Figure 2}

Cumulative average nitrate-nitrogen $\left(\mathrm{NO}_{3}^{-}-\mathrm{N}\right)$ leached from the soil cylinders sampled throughout the study period from the soils managed with conventional and strip tillage. The timeline below the graph illustrates the land management, including crop rotation: peanuts, cotton, and winter cover (wc); and the application of poultry litter and fertilizer (f) according to table 1.

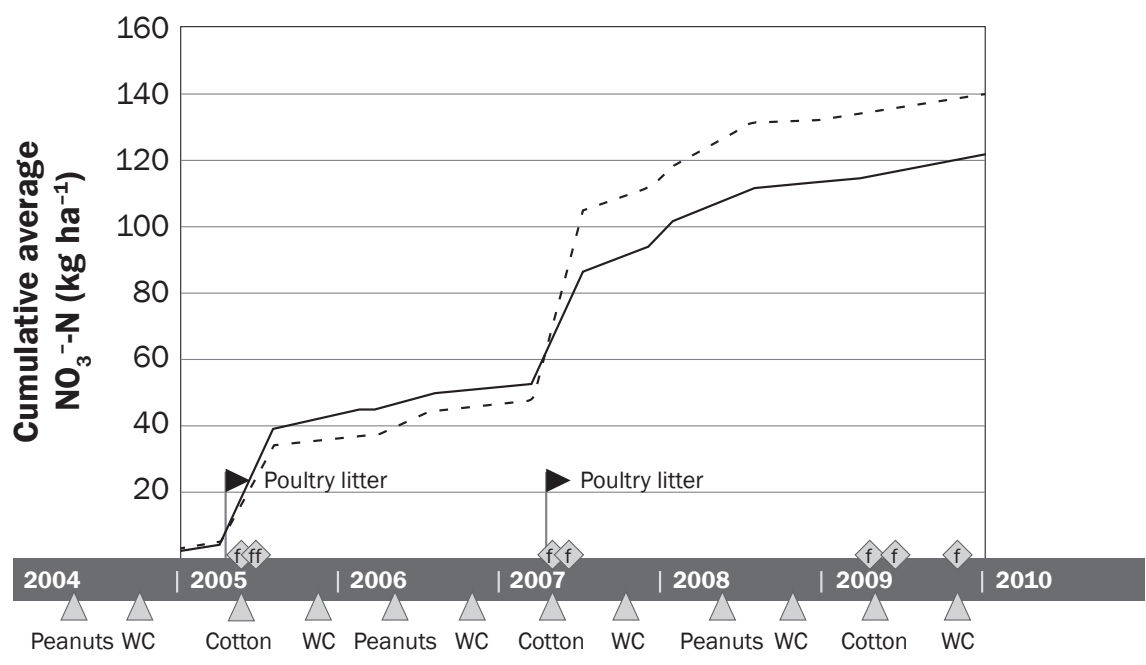

\section{Legend}

- - Conventional tillage - Strip tillage

of management type, leaching from the top $15 \mathrm{~cm}$ (6 in) of soil is an important pathway for dissolved $\mathrm{N}$ loss from the rooting zone in this landscape. In the current study, $\mathrm{NO}_{3}^{-}-\mathrm{N}$ leaching represents an overestimation of $\mathrm{N}$ loss because $\mathrm{N}$ loss due to plant uptake was not measured. A major challenge for the future is to minimize $\mathrm{NO}_{3}^{-}-\mathrm{N}$ in the soil from reaching ground and surface waters while maintaining, if not increasing, crop productivity (Kirchmann et al. 2002). In addition, finding the right balance between $\mathrm{N}$ supply and crop demand without excess or deficiency is key to optimize yield, profit, and environmental protection (Cassman et al. 2002). This research suggests that the use of ST systems may improve plant $\mathrm{N}$ availability by more than $27 \mathrm{~kg} \mathrm{ha}^{-1} \mathrm{y}^{-1}\left(24 \mathrm{lb} \mathrm{ac}^{-1}\right.$ $\left.\mathrm{yr}^{-1}\right)$ in the sandy landscapes of the southeastern Coastal Plain region through microbial cycling of organic $\mathrm{N}$.

\section{Acknowledgements}

This research is a contribution of the USDA Agricultural Research Service (ARS) GRACEnet Project and the USDA ARS Gulf Atlantic Coastal Plain Long-Term Agroecosystem Research site. The authors are grateful for

much more $\mathrm{N}$ would likely be leached from the rooting zone.

The C:N ratios of the extracted, nonfumigated soils were generally lower than the $\mathrm{C}: \mathrm{N}$ ratios of the whole soil samples (tables 3 and 6), suggesting a higher C lability and $\mathrm{N}$ availability of the extracted material. The organic material rendered extractable with chloroform fumigation is relatively rich in $\mathrm{N}$ as shown by even lower $\mathrm{C}: \mathrm{N}$ ratios (table 6). The change in C:N ratios after fumigation is due to the release of microbial biomass following membrane rupture and from solubilization of nonpolar SOM components by the chloroform. The microbial C:N ratios were much lower, but still represented realistic values of soil microbial communities (Franzluebbers et al. 1999; Harris et al. 1997). This may result from the mineralization of variable proportions of the biomass $\mathrm{N}$ and may lead to net immobilization of $\mathrm{N}$, especially if fungi are prevalent (Paul et al. 1999). These results are typical of narrowing C:N ratios as organic $\mathrm{N}$ is cycled from decomposable plant material to living microbial biomass and is consistent with the concept of $\mathrm{N}$ cycling by soil microflora and the leaking of $\mathrm{N}$ as a mechanism contributing to plant $\mathrm{N}$ availability.

\section{Summary and Conclusions}

The $\mathrm{N}$ applied to agricultural soils is taken up by plants, lost to the atmosphere via denitrification, leached into the ground or surface waters, or incorporated into SOM (Bosch et al. 2015; Di and Cameron 2002). Because of our experimental design, we did not measure the amount of $\mathrm{N}$ assimilated into plant biomass or lost to denitrification. However, results from the current experiments demonstrate that regardless of tillage treatment, microbial biomass represents a small percentage of soil TN but that at any point in time, is equal to or higher than the TIN pool. Although no apparent trend was observed in microbial biomass with cylinder collection date and individual annual averages, the cumulative five-year average indicated that microbial biomass was higher with ST compared to CT. We also found that $\mathrm{NO}_{3}^{-}-\mathrm{N}$ leaching may contribute to substantial $\mathrm{N}$ losses from sandy soils in the southeastern Coastal Plain of the United States. The fiveyear cumulative amount of $\mathrm{NO}_{3}^{-}-\mathrm{N}$ leached was $141 \mathrm{~kg} \mathrm{~N} \mathrm{ha}^{-1}\left(126 \mathrm{lb} \mathrm{N} \mathrm{ac}^{-1}\right)$ and 122 $\mathrm{kg} \mathrm{N} \mathrm{ha}^{-1}\left(109 \mathrm{lb} \mathrm{N} \mathrm{ac}^{-1}\right)$ from soils managed with CT and ST, respectively. These values are higher than the five year average subsurface flow loadings of 45 and $99 \mathrm{~kg} \mathrm{~N} \mathrm{ha}^{-1}$ for CT and ST, respectively (99 and $88 \mathrm{lb} \mathrm{N} \mathrm{ac}^{-1}$; Bosch et al. 2015), and suggest that regardless the assistance of the following research technicians with the USDA ARS Southeast Watershed Research Laboratory in Tifton, Georgia: Thoris Green, Regina Hornbuckle, Lorine Lewis, Bobby Shiver, and Coby Smith.

\section{Disclaimer}

Mention of trade names, commercial products, or companies in this publication does not imply recommendation or endorsement by USDA Agricultural Research Service.

\section{References}

Al-Kaisi, M.M., X. Yin, and M.A. Licht. 2005. Soil carbon and nitrogen changes as influenced by tillage and cropping systems in some Iowa soils. Agriculture Ecosystems and Environment 105:635-647.

Batjes, N.H. 1996. Total carbon and nitrogen in the soils of the world. European Journal of Soil Science 47:151-163.

Bosch, D.D., T.L. Potter, C.C. Truman, C. Bednarz, and T.C. Strickland. 2005. Surface runoff and lateral subsurface flow as a response to conservation tillage and soil-water conditions. Transactions of the American Society of Agricultural Engineers 48:2137-2144.

Bosch, D.D., T.L. Potter, T.C. Strickland, and R.K. Hubbard. 2015. Dissolved nitrogen, chloride, and potassium loss from fields in conventional and conservation tillage. American Society of Agricultural and Biological Engineers 58:1559-1571.

Bosch, D.D., C.C. Truman, T.L. Potter, L.T. West, T.C. Strickland, and R.K. Hubbard. 2012. Tillage and slope 


\section{Table 6}

Seasonal values of soil microbial data, including extractable, chloroform-extractable, and microbial biomass carbon (MBC), nitrogen (MBN), and $\mathrm{C}: \mathrm{N}$ ratios. Values are averages \pm standard error $(n=6)$. Bold font indicates a significant difference $(p \leq 0.05)$ between conventional (CT) and strip tillage (ST) for a particular cylinder collection date. Values within a treatment row followed by different lowercase letters indicate significant differences $(p \leq 0.05)$ between $\mathrm{N}$ pools. Values within a treatment row followed by different uppercase letters indicate significant differences $(p \leq 0.05)$ between $\mathrm{N}$ pool $\mathrm{C}: \mathrm{N}$ ratios.

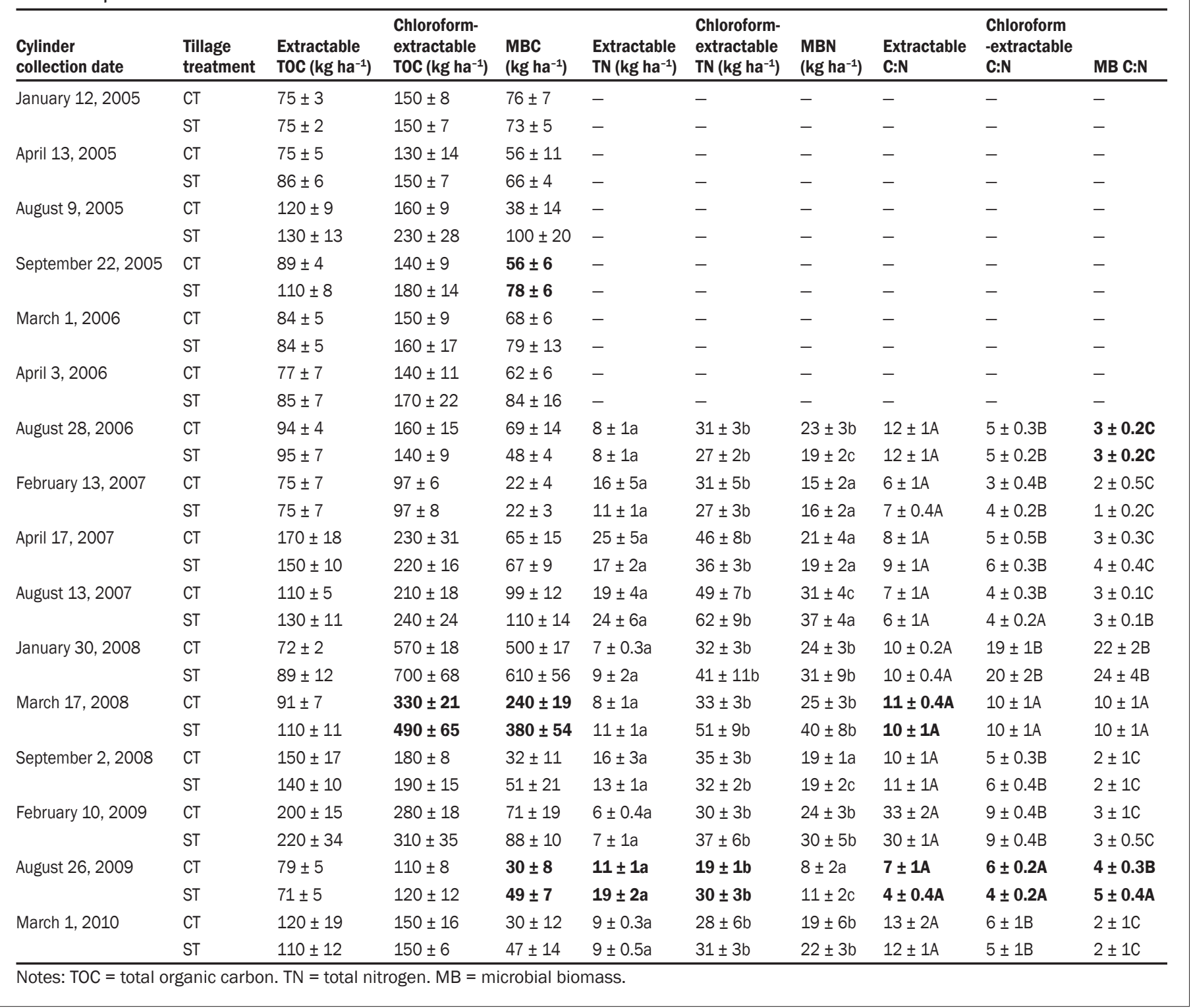

position impact on field-scale hydrologic processes in the South Atlantic Coastal Plain. Agricultural Water Management 111:40-52

Bremer, E., and C. Van Kissel. 1992. Plant-available nitrogen from lentil and wheat residues during a subsequent growing season. Soil Science Society of America Journal 56:1155-1160.

Brookes, P.C., A. Landman, G. Pruden, and D.S. Jenkinson. 1985. Chloroform fumigation and the release of soil nitrogen: A rapid direct extraction method to measure microbial biomass nitrogen in soil. Soil Biology and Biochemistry 17:837-842.
Cassman, K.G., A. Dobermann, and D.T. Walters. 2002. Agroecosystems, nitrogen-use efficiency, and nitrogen management. Ambio 31:132-140.

Causarano, H.J., A.J. Franzluebbers, J.N. Shaw, D.W. Reeves, R.L. Raper, and C.W. Wood. 2008. Soil organic carbon fractions and aggregation in the Southern Piedmont and Coastal Plain. Soil Science Society of America Journal 72:221-230.

Dabney, S.M., J.A. Delgado, and D.W. Reeves. 2001. Using winter cover crops to improve soil and water quality. Communications in Soil Science and Plant Analysis 32:1221-1250.
Di, H.J., and K.C. Cameron. 2002. Nitrate leaching in temperate agroecosystems: Sources, factors and mitigating strategies. Nutrient Cycling in Agroecosystems 46:237-256.

Endale, D., D.D. Bosch, T.L. Potter, and T.C. Strickland. 2014. Sediment loss and runoff from cropland in a southeast Atlantic Coastal Plain landscape. Transactions of the American Society of Agricultural and Biological Engineers 57:1611-1626.

Feyereisen, G.W., R. Lowrance, T.C. Strickland, D.D. Bosch, and J.M. Sheridan. 2008. Long-term stream chemistry trends in the southern Georgia Little River Experimental Watershed. Journal of Soil and 
Table 7

Annual averages of soil microbial data, including extractable, chloroform-extractable, and microbial biomass $\mathrm{C}, \mathrm{N}$, and C:N ratios. Values are averages \pm standard error. Bold font indicates a significant difference $(p \leq 0.05)$ between conventional (CT) and strip tillage (ST) for a particular year. Values within a treatment row followed by different lowercase letters are significantly different $(p \leq 0.05)$ between years. Five-year averages followed by different uppercase letters indicate significant differences $(p \leq 0.05)$ between $\mathrm{N}$ pools and $\mathrm{N}$ pool C: $\mathrm{N}$ ratios.

\begin{tabular}{|c|c|c|c|c|c|c|c|}
\hline Parameter & $\begin{array}{l}\text { Tillage } \\
\text { treatment }\end{array}$ & $\begin{array}{l}2005 \\
(n=24) \\
\end{array}$ & $\begin{array}{l}2006 \\
(n=18) \\
\end{array}$ & $\begin{array}{l}2007 \\
(n=18) \\
\end{array}$ & $\begin{array}{l}2008 \\
(n=18) \\
\end{array}$ & $\begin{array}{l}2009 \\
\left(n=18^{*}\right) \\
\end{array}$ & $\begin{array}{l}\text { Five-year average } \\
(n=60 \text { or } 96)\end{array}$ \\
\hline \multirow[t]{2}{*}{ Extractable TOC $\left(\mathrm{kg} \mathrm{ha}^{-1}\right)$} & CT & $90 \pm 5 a$ & $85 \pm 3 a b$ & $120 \pm 11 b$ & $110 \pm 10 a b$ & $130 \pm 15 b$ & $110 \pm 4$ \\
\hline & ST & $98 \pm 6 a$ & $88 \pm 3 a b$ & $120 \pm 9 a c$ & $110 \pm 8 \mathrm{ac}$ & $130 \pm 19 a$ & $110 \pm 5$ \\
\hline \multirow[t]{2}{*}{ Chloroform-extractable TOC (kg ha-1) } & CT & $150 \pm 5 a$ & $150 \pm 7 a$ & $180 \pm 18 a$ & $360 \pm 40 b$ & $180 \pm 19 a$ & $200 \pm 12$ \\
\hline & ST & $180 \pm 10 a$ & $160 \pm 10 a$ & $190 \pm 18 a$ & $460 \pm 59 b$ & $200 \pm 23 a$ & $230 \pm 17$ \\
\hline \multirow[t]{2}{*}{$\operatorname{MBC}\left(\mathrm{kg} \mathrm{ha}^{-1}\right)$} & CT & $56 \pm 5 a$ & $66 \pm 5 a b$ & $62 \pm 10 a$ & $260 \pm 47 c$ & $44 \pm 9$ ad & $95 \pm 12$ \\
\hline & ST & $80 \pm 6 a$ & $70 \pm 7 b$ & $68 \pm 11 a b$ & $350 \pm 61 c$ & $61 \pm 7 b$ & $120 \pm 16$ \\
\hline \multirow[t]{2}{*}{ Extractable TN (kg ha $\left.{ }^{-1}\right)$} & CT & - & $8 \pm 1 a$ & $20 \pm 3 b$ & $11 \pm 1 a$ & $9 \pm 1 a$ & $13 \pm 1 \mathrm{~A}$ \\
\hline & ST & - & $8 \pm 1 a$ & $17 \pm 2 b$ & $11 \pm 1 a$ & $12 \pm 1 a$ & $13 \pm 1 \mathrm{~A}$ \\
\hline \multirow[t]{2}{*}{ Chloroform-extractable TN (kg ha-1) } & CT & - & $31 \pm 3 a$ & $42 \pm 4 a b$ & $33 \pm 2 a b$ & $26 \pm 2 a c$ & $33 \pm 2 B$ \\
\hline & ST & - & $27 \pm 2 a$ & $42 \pm 5 a$ & $41 \pm 5 a$ & $33 \pm 2 a$ & $37 \pm 2 \mathrm{~B}$ \\
\hline \multirow[t]{2}{*}{ MBN $\left(\mathrm{kg} \mathrm{ha}^{-1}\right)$} & CT & - & $23 \pm 3 a$ & $22 \pm 2 a$ & $23 \pm 1 a b$ & $17 \pm 3$ ac & $21 \pm 1 C$ \\
\hline & ST & - & $19 \pm 2 a$ & $24 \pm 3 a$ & $30 \pm 4 a$ & $21 \pm 3 a$ & $24 \pm 2 C$ \\
\hline \multirow[t]{2}{*}{ Extractable C:N } & CT & - & $12 \pm 1 a$ & $7 \pm 1 b$ & $10 \pm 0.3 a$ & $18 \pm 3 a$ & $12 \pm 1 \mathrm{~A}$ \\
\hline & ST & - & $12 \pm 1 a$ & $8 \pm 0.5 b$ & $10 \pm 0.4 a$ & $15 \pm 3 a b$ & $11 \pm 1 \mathrm{~A}$ \\
\hline \multirow[t]{2}{*}{ Chloroform-extractable C:N } & CT & - & $5 \pm 0.3 a$ & $4 \pm 0.3 a b$ & $11 \pm 1 c$ & $7 \pm 0.5 \mathrm{ad}$ & $7 \pm 1 \mathrm{~B}$ \\
\hline & ST & - & $5 \pm 0.2 a$ & $5 \pm 0.3 a$ & $12 \pm 2 b$ & $6 \pm 0.5 a$ & $7 \pm 1 \mathrm{~B}$ \\
\hline \multirow[t]{2}{*}{ MB C:N } & CT & - & $3 \pm 0.2 a$ & $3 \pm 0.2 a b$ & $11 \pm 2 \mathrm{ac}$ & $3 \pm 0.4 a b$ & $5 \pm 1 C$ \\
\hline & ST & - & $3 \pm 0.2 a$ & $3 \pm 0.3 a$ & $12 \pm 2 b$ & $4 \pm 0.4 a$ & $6 \pm 1 C$ \\
\hline
\end{tabular}

Notes: $\mathrm{TOC}=$ total organic carbon. $\mathrm{MBC}=$ microbial biomass $\mathrm{C}$. TN = total nitrogen. $\mathrm{MBN}=$ microbial biomass $\mathrm{N}$. MB = microbial biomass.

*The final cylinder was collected at the beginning of March of 2010 and was included in the 2009 annual average for a better estimation of significant differences between tillage treatments in that year.

Water Conservation 63(6):475-486, doi:10.2489/ jswc.63.6.475.

Franzluebbers, A.J., R.L. Haney, and F.M. Hons. 1999 Relationships of chloroform fumigation-incubation to soil organic matter pools. Soil Biology and Biochemistry 31:395-405.

Franzluebbers, A.J., J.A. Stuedemann, H.H. Schomberg, and S.R. Wilkinson. 2000. Soil organic C and N pools under long-term pasture management in the Southern Piedmont USA. Soil Biology and Biochemistry 32:469-478.

Halvorson, A.D., B.J. Wienhold, and A.L. Black. 2002 Tillage, nitrogen, and cropping system effects on soil carbon sequestration. Soil Science Society of America Journal 66:906-912.

Harris, D., R.P. Voroney, and E.A. Paul. 1997. Measurement of microbial biomass $\mathrm{N}: \mathrm{C}$ by chloroform fumigation-incubation. Canadian Journal of Soil Science 77:507-514.

Herai, Y., K. Kouno, M. Hashimoto, and T. Nagaoka. 2006. Relationships between microbial biomass nitrogen, nitrate leaching and nitrogen uptake by corn in a compost and chemical fertilizer-amended regosol. Japanese Society of Soil Science and Plant Nutrition 52:186-194.

Holland, J.M. 2004. The environmental consequences of adopting conservation tillage in Europe: Reviewing the evidence. Agriculture, Ecosystems and Environment 103:1-25.

Honeycutt, C.W., T.S. Griffin, B.J. Wienhold, B. Eghball, S.L. Albrecht, J.M. Powell, B.L. Woodbury, K.R. Sistani, R.K. Hubbard, H.A. Torbert, R.A. Eigenberg, R.J. Wright, and M.D. Jawson. 2005. Protocols for nationally coordinated laboratory and field research on manure nitrogen mineralization. Communications in Soil Science and Plant Analysis 36:2807-2822.

Hubbard, R.K., D.D. Bosch, L.K. Marshall, T.C. Strickland, D. Rowland, T.S. Griffin, C.W. Honeycutt, S.L. Albrecht, K.R. Sistani, H.A. Torbert, B.J. Wienhold, B.L. Woodbury, and J.M. Powell. 2008. Nitrogen mineralization from broiler litter applied to southeastern Coastal Plain soils. Journal of Soil and Water Conservation 63(4):182-192, doi:10.2489/ jswc.63.4.182

Hubbard, R.K., G.J. Gascho, J.E. Hook, and W.G. Knisel. 1986. Nitrate movement into shallow groundwater through a coastal plain sand. Transactions of the American Society of Agricultural Engineers 29:1564-1571.

Hubbard, R.K., and R.R. Lowrance. 1996. Solute transport and filtering through a riparian forest. Transactions of the American Society of Agricultural Engineers 39:477-488.

Hubbard, R.K., and J.M. Sheridan. 1983. Water and nitrate-nitrogen losses from a small upland coastal plain watershed. Journal of Environmental Quality 12:291-295.

Hubbard, R.K., J.M. Sheridan, R.R. Lowrance, D.D. Bosch, and G.Vellidis. 2004. Fate of nitrogen from agriculture in the southeastern Coastal Plain. Journal of Soil and Water Conservation 59(2):72-86.

Iversen, T.M., R. Grant, and K. Nielsen. 1998. Nitrogen enrichment of European inland and marine waters with special attention to Danish policy measures. Environmental Pollution 102:771-780.

Kalkhoff, S.J., L.E. Hubbard, M.D. Tomer, and D.E. James. 2016. Effect of variable annual precipitation and nutrient input on nitrogen and phosphorus transport from two Midwestern agricultural watersheds. Science of the Total Environment 559:53-62.

Kirchmann, H., A.E.J. Johnston, and L.F. Bergström. 2002. Possibilities for reducing nitrate leaching from agricultural land. Ambio 31:404-408

Kristensen, H.L., K. Debosz, and G.W. McCarty. 2003. Short-term effects of tillage on mineralization of nitrogen and carbon in soil. Soil Biology and Biochemistry 35:979-986.

Lal, R., D.C. Reicosky, and J.D. Hanson. 2007. Evolution of the plow over 10,000 years and the rationale for no-till farming. Soil and Tillage Research 93:1-12.

McCarty, G.W., J.J. Meisinger, and F.M.M. Jenniskens. 1995. Relationships between total-N, biomass- $\mathrm{N}$ and active- $\mathrm{N}$ 
in soil under different tillage and $\mathrm{N}$ fertilizer treatments. Soil Biology and Biochemistry 27:1245-1250.

Myrold, D.D. 1987. Relationship between microbial biomass nitrogen and a nitrogen availability index. Soil Science Society of America Journal 51:1047-1049.

NADP (National Atmospheric Deposition Program). 2013. National Trends Network, Chula, GA site. http://nadp.sws.uiuc.edu/data/sites/siteDetails. aspx?net=NTN\&id= GA99.

Paul, E.A., D. Harris, M.J. Klug, and R.W. Ruess. 1999. The determination of microbial biomass. In Standard Soil Methods for Long-Term Ecological Research, eds. G.P. Robertson, D.C. Coleman, C.S. Bledsoe, and P. Sollins, 291-317. New York, NY: Oxford University Press.

Potter, T.L., D.D. Bosch, and T.C. Strickland. 2014. Comparative assessment of herbicide and fungicide runoff risk: A case study for peanut production in the Southern Atlantic Coastal Plain (USA). Science of the Total Environment 491:1-10.

Potter, T.L., D.D. Bosch, and T.C. Strickland. 2015. Tillage impact on herbicide loss by surface runoff and lateral subsurface flow. Science of the Total Environment 530-531:357-366.

Saffigna, P.G., D.S. Powlson, P.C. Brookes, and G.A. Thomas. 1989. Influence of sorghum residues and tillage on soil organic matter and microbial biomass in an Australian Vertisol. Soil Biology and Biochemistry 21:759-765.

Sainju, U.M., W.B. Stevens, R.G. Evans, and W.M. Iversen. 2013. Irrigation system and tillage effects on soil carbon and nitrogen fractions. Soil Science Society of America Journal 77:1225-1234.

Schnepf, M., and C. Cox. 2006. Environmental Benefits of Conservation on Cropland:The Status of our Knowledge. Ankeny, IA: Soil and Water Conservation Society.

Strickland, T.C., B.T. Scully, R.K. Hubbard, D.G. Sullivan, Z. Abdo, M.R. Savabi, R.D. Lee, D.M. Olson, and G.L. Hawkins. 2015. Effect of conservation practices on soil carbon and nitrogen accretion and crop yield in a corn production system in the southeastern coastal plain, United States. Journal of Soil and Water Conservation 70(3):170-181, doi:10.2489/jswc.70.3.170.

Thorburn, P.J., J.S. Biggs, K.L. Weier, and B.A. Keating. 2003. Nitrate in groundwaters of intensive agricultural areas in coastal Northeastern Australia. Agriculture, Ecosystems and Environment 94:49-58.

USDA NRCS. 2006. Conservation Practice Standard No. 329: No-till and strip till/direct seed. Washington, DC: USDA Natural Resources Conservation Service.

West, T.O., and W.M. Post. 2002. Soil organic carbon sequestration rates by tillage and crop rotation: A global data analysis. Soil Science Society of America Journal 66:1930-1946. 